\title{
Consumer Redress Channels Under Nigerian Laws: A Comparative Analysis
}

\author{
Dr Rose Ohiama Ugbe* Brian F. I. Anyatang B.E. Kooffreh Anne Uruegi Agi \\ Faculty of Law, University of Calabar. Nigeria
}

\begin{abstract}
The relational disparities between the Nigerian consumers and suppliers have been pronounced that a Nigerian consumer can only be described as a subject but not a king. It is however, palpable that there is no economy in the world that is devoid of consumer abuses and exploitation. It is regrettable that Nigerian consumers appear to be the most abused and most exploited by manufacturers (local and international), suppliers and retailers. This paper seeks to catalogue consumer redress channels for consumer education in Nigeria vis-a-vis what is obtainable in other jurisdictions with a view to making recommendations for effective consumer protection.
\end{abstract}

Keywords: Consumer, Protection, Redress, Legislation, Channels, Comparative

DOI: $10.7176 / \mathrm{JLPG} / 104-03$

Publication date: December $31^{\text {st }} 2020$

\subsection{Introduction}

Consumer protection has increasingly become a critical and significant issue in national, regional and international market places. The reason is not far-fetched, as it is a veritable technique of addressing imbalances between suppliers and consumers, and to correct the inherent disparities in the market relationship between the duo in terms of bargaining power, knowledge and many other resources. The advent of globalization has also intensified the need to protect consumers as the world has become a single global market for global consumers and for the sale of different commodities and services. There is no gainsaying the fact that globalization has significantly informed the regular revision of many countries' consumer protection legislation. For instance, Nigeria and Malaysia repealed and amended their Consumer Protection Act 1992, and Consumer Protection Act 1999 in 2018 and 2019 respectively. In Nigeria the Federal Competition and Consumer Protection Act 2018 (FCCPA 2018) is the extant law while in Malaysia it is the Consumer Protection (Amendment) Act 2019. In Nigeria, consumer abuses and exploitation are most discernable in the use of fake foreign labels to attach to inferior foreign and local goods and products, erasure of expiring dates from expired goods. Some antibiotic capsules contain talcum powder and the sale of substandard products (the litany of these wrongs is endless) with total disregard for the consumer's rights, health, welfare and interest. Iwok and Kooffreh, (2014) noted that these consumer abuses and exploitation by manufacturers, suppliers and retailers cut across the length and breadth of not only foods and drugs but also tourism, leisure, transport, telecommunications, financial services and energy sectors. The vexed issues are product safety, quality, food and drugs, safety and labeling product defects and standards. This work examines Consumer Redress Channels in Nigeria and other jurisdictions as well as United Nations Conference on Trade and Development's (UNCTAD'S) Standards, Guidelines and Best Practices for Consumer Protection with a view to making recommendations for a better consumer protection mechanism in Nigeria.

\subsection{Literature Review}

2.1 Consumer- Simply put, a consumer is someone who buys products for consumption and personal use. According to Black's Law Dictionary (2019) consumer is "a person who buys goods or services for personal, family or household use with no intention of resale: natural person who uses products for personal rather than business purposes". The definition by Black's Law Dictionary confines “consumer" to only natural persons who purchase goods or services for personal, family or household use, but is exclusive of non-natural persons who may buy raw materials for production purposes. The repealed Nigerian Consumer Protection Council Act 1992 defined a consumer as "an individual who purchases, uses, maintains or disposes products or services". The Federal Competition and Consumer Protection Act, 2018 also defines consumer as:

including any person who purchases or offers to purchase goods otherwise than for the purpose of resale but does not include a person who purchases any goods for the purpose of using them in the production or manufacture of any other goods or articles for sale; or to whom a service is rendered.

Generally, the aforesaid definitions exclude non- natural persons that may buy raw materials for production purposes. Aasker and Day (1974) notes that there is no consensus among draftsmen and commentators on the meaning of the term, consumer. While some restrict the term to a contractual relationship, others prefer expanded meaning that includes persons with no contractual bargains as well as corporations. Sampathkumar, R. (2002) declared that consumerism is society's effort to redress the discrepancy in trade dealings between sellers and consumers. Section 3(1) of the Consumer Protection Act 1999 of Malaysia defines a consumer as "a person who 
either obtains or uses a product or services for any personal or household purposes or re-supplies a product or services in trade, manufacturing, repairing, or treating process. Zakuan and Rahmah Ismail (2019) noted that consumers are those who purchase products and services that are not used for commercial purposes".

2.2 Redress: Redress is defined in the Chambers $21^{\text {st }}$ Century Dictionary (1996) as, setting right or compensation for something wrong; to make even or equal again, money etc, paid as compensation for loss of wrong done. Black's Law Dictionary also defines redress as relief, remedy or pecuniary damages as opposed to equitable reliefs. It is pertinent to emphasize that such reliefs,remedies or money, damages for product defects must be pursued and obtained by the plaintiff within the period of time stipulated by the statute of limitation, failing which the consumer would have no redress. Hazlina Shaik Md Noor Alam (2019) posited that in an effort to attain redress, the consumer may look for remedy away from contract law, by employing the law of tort, provided he establishes negligence.

2.3 Channel: The New Webster's International Dictionary (2004) refers to it as a course or agency through which something can be communicated.Channel in this paper means ways and agencies through which a consumer can ventilate his grievances against the manufacturer, supplier or retailer for product defects.

2.4 Scholarly perspective on consumer redress

Day and Landon, (1977) classify dissatisfied consumers redress channels into public or private redress actions. They maintain that in private redress actions, consumers basically express their grievances to their acquaintances and relations. Singh (1990) noted that consumers who engage in private redress actions are known as "voicers". They do not necessarily channel their grievance to the seller, but instead employ acts of "Negative words of mouth" (NWOM) by means of social channels to their associates, contacts, and relations. Singh and Wilkes, (1996) criticised this approach of consumer redress stating that it barely goes unnoticed by the Manufacturer, and as such they are not perturbed in anyway whatsoever. Davidow and Dacin, (1997) asserted that Public redress actions consist of a more formal complaint approach, where the consumer put forward his grievances to governmental bureau, or public consumer protection council. Mikhaylov et al. (2016) examined circumstances that may cause an aggrieved consumer to take no action against a producer of a defective product to include capital intensive complaint procedures, inadequate capability of the end user to embark on complaint action. Roh (2015) exposed four rationales for no complaint action on the part of the consumer to include sympathetic trust, lack of sensitivity, want of time and societal restraints. Istanbulluoglu et al., (2017) further expanded the scope of private redress actions to include boycotting the producer or change of brand, intentional cessation of using a particular merchandise/service or ending patronage. In other severe cases, he stated that consumers may publicize their discontent through the manufacturer's website or social media handle ahead of boycotting.

Day and Landon, (1977) assert that public redress actions by a consumer is a means of looking for refund and compensation directly from the manufacturer especially where the consumer has a good case against the manufacturer. Gyasi, (2012) maintained that a resort to legal action is a last option for a disgruntled customer although it is the most expensive redress mechanism. Sune Donoghue and Helena M.de Klerk (2009) declared that the best way to protect consumers is by instituting a redress atmosphere that would guarantee equitable redress and also an understanding and approval of the consumer. Dennis Odigie \& Job Odion (2011) disclosed that the courts, appropriate consumer protection laws and enforcement group have been unsuccessful at offering protection to the consumer. As a result, the consumer is only left defenceless and at the clemency of unforgiving producer and embellished sellers.

Etefia E. Ekanem (2011) postulated that it is apparent that away from the setback posed by an absence of suitable legislation, the court has failed in being a saviour of last resort, when an aggrieved consumer approaches it for redress. Spencer Weber Waller, Jillian G. Brady and R.J. Acosta (2011) stated that even though U.S. instruments for consumer protection often exist independently from one other, what the general scheme lacks in centralization, it possesses in profundity and multiplicity of protection for a consumer. Its potency is the assortment of governmental personnel's, prescribed legal privileges, and legal remedies shielding consumers. Van Heerde, C. \& Barnard, J. (2011) stated that consumer rights are worthless if they lack enforcement. The European Union placed great importance on the consumer redress, by creating significant EU Directives and formulating Green Papers on the subject of consumer protection and being in constant contact with the states party. Rachagan, (1992) stated that the law plays a vital role in giving that protection to consumers in the marketplace.

From the foregoing review of some literatures, comparative analysis of consumer redress and examination of UNCTAD'S Guidelines are not undertaken. This paper fills those gaps. However, discussions on consumer redress will be useful to this paper.

\subsection{Methodology}

This research relied mainly upon an assessment of primary legal texts, including treaties, statutes and case laws. An analysis of secondary legal sources, including legal periodicals, legal reports, conference papers, books, journal articles, internet sources and newspaper reports were employed. The methodology through which the legal analysis in this paper was conducted is primarily doctrinal. The study also involved a comparative analysis of consumer redress approaches and practices in different jurisdictions. There was also a descriptive and analytical approach to 
this research.

\subsection{United Nations Conference on Trade and Development's (UNCTAD'S) Standards, Guidelines and Best Practices for Consumer Protection}

UNCTAD is an organ of the United Nation's saddled with the responsibility of regulating trade and development of member states. It serves as the mainspot for consumer protection matters within the United Nations structure. Its sub-organs include the World Trade Organization (WTO), the Group of 20 (G20), Organization of Economic Co-operation and Development (OECD). The primary focus and commitment of UNCTAD is to promote the guidelines as well as encourage concerned member states to build responsiveness of the various means of promoting consumer protection nationally through the stipulation of public and private goods and services in partnership with businesses and civil society. It is necessary to emphasize that UNCTAD's guidelines, standards and best practices on consumer protection are not binding on member states but only serve as a guide.

4.1 Regulatory frameworks: UNCTAD prescribes that private or public municipal laws should be enacted to:

- Enforce definite rights and obligations on parties as well as secure proactive enforceability

- Make equal the uneven liaison among stronger manufacturers, suppliers, retailers) and weaker parties (consumers).

- Use state involvement to remedy market place collapse in the public interest and to punish defaulting parties

- Exercise state control over manufacturers and suppliers through registration and licensing procedures to ensure that consumers are protected from deceitful and scandalous suppliers, and from defective goods and services.

- Make certain that goods and services put on sale in the market have minimum standard of safety and quality.

- Guarantees right to use to certain basic goods and services that are necessary for life. By incorporating all these elements into their municipal laws, member states will protect and guarantee the rights and interests of consumers in their domains.

4.2 Agencies Responsible For Consumer Protection

UNCTAD states that government agencies are ministries and departments in charge of consumer protection, who have the responsibilities to administer and enforce consumer safety laws. Legal and non-legal standard bodies are government and non-governmental bodies recognized to lay down principles for product safety, quality control and issuance of certification marks, for instance, Nigerian Standards Organization (NSO) an affiliate of International Standards Organization (ISO).

Professional and industrial associations evolve codes of conduct for members with the co-operation of consumer protection agencies, with the aim of handling complaints and discipline of their members. Self-and-co-regulatory bodies are professional bodies such as Nigerian Bar Association (NBA), American Bar Association (ABA) etc, which assist the government to regulate the conduct of their members through compliance with their ethical codes, corporate social responsibility and corporate governance. Consumer associations represent interests and voice of their individual consumer members.

4.3 Institutional and Legal Frameworks/Consumer Redress Mechanisms

UNCTAD prescribes establishment of institutional mechanisms such as National consumer policy (which should specify the state's approach to consumer protection and rights and responsibilities of state organs in charge of consumer protection), designation of consumer protection agency (agencies). Consumer protection laws and codes (hard and soft laws) should cover rights of consumers, standards of goods and services.

4.4 Consumer Education and Information Programmes and International Co- Operation/ Networking

UNCTAD advocates that municipal governments should organize regular consumer education and information programmes through workshops, conferences and the media to equip and empower their consumers with knowledge to protect themselves.Consumer protection agencies in the different countries should co- operate and network so as to bring about constant swap over and giving out of information, technological education and aptitude building to enable them implement and benefit from reciprocal enforcement, and multilateral agreements on consumer protection.

4.5 Establishment of Mechanisms for Monitoring and Surveillance

UNCTAD advises that municipal government should put in place mechanisms for the monitoring and surveillance of consumers' problems, handle consumers' complain, monitor prices in the market place as well as carry out regular market/household surveys in order to identify consumer problems. These mechanisms assist consumer safety establishment to take preventative actions on consumer harms before they escalate beyond redemption.

4.6 Constitutional Provisions-

UNCTAD advocates that countries should build into their constitutions' provisions on consumer protection as has been done by some countries such as south Africa, Egypt, Mexico, Poland, El Salvador, Switzerland, European charter of fundamental rights etc (Article 38). The UNCTAD advocacy on constitutional protection of consumers 
is predicated by the fact that the constitution is the grundnorm (supreme law of a country) and is superior to other municipal legislation.

\subsection{Consumer Redress Channels in Nigeria}

There are no express or implied constitutional provisions on consumer protection in Nigeria. However, the Constitution of the Federal Republic of Nigeria, (CFRN) 1999 as amended confers limited legislative powers in the Exclusive list on the National Assembly to make laws on trade and commerce, institution of an organ to set down and implement values of goods and commodities accessible for sale; be in charge of prices of goods and commodities selected by the national assembly, and weights and measures (Second schedule, section 62 (d-e) and section 65). It also confers the adjudicatory powers on the Federal High Court to adjudicate on weights and measures (Section 251(1) (O) FRCN). Even though there is absence of outright constitutional provisions on consumer protection in Nigeria, Nigerian consumers have the following channels in which they can seek redress for purchasing defective and substandard goods and services: common law remedies (civil and contract-based) and statutory remedies.

5.1 Civil remedies: These are tort-based actions, the remedy of which is a claim for damages. Tort-based actions are necessitated by breach of warranty by suppliers, manufacturers, diminution or extinction of the price, breach of conditions. In all these circumstances, the buyer may sustain an action against the seller for infringement (Section 53(2) of the sale of Goods Act, CAP. 30 LFN 2004). The three basic situations in which the consumer is entitled to sue for damages include: anywhere the seller is in breach of warranty (Section 12 (2), where he elects to treat a breach of condition as a breach of warranty (Section 12(1), and where he is obligated to treat a breach of condition as a breach of warranty (Section 12(3), Damages awarded for tort-based remedies by Nigerian courts are non-pecuniary, special or general damages. Damages are measured as monetary compensation and based on remoteness of damage, breach of warranty and breach of warranty of quality (Section 53(2). In Hadley v Baxendale (1854) the English court laid down the rules for the measurement of damages for breach of warranty as adumbrated by Alderson, B. The court's rules on award of damages for breach of warranty are premised on fairness and reasonability by the seller and consumer (buyer). The rules are also in accord with section 53(2) of Sale of Goods Act (SOGA) 1893.

In the Nigerian case of Mann Poole v Salami Agbaje (1951), the defendants failed to deliver some cocoa bargained for, and the plaintiff were constrained to obtain supply at an extra price in order to fulfill a contract with their customers. It was held that the extra price was a loss naturally resulting in the ordinary events from the breach. It is submitted that the decision of the court was conservative because there was a breach of contract and the defendant should have compensated the plaintiff for the breach. Section 53(3) of The Sale of Goods Act explicitly lays down the rule for the measure of damages for breach of quality, that is, there must be prima facie difference between the value of the goods at the time of delivery to the buyer and the value they would have had, if they had answered to the warranty or the difference between the goods delivered and those contracted for. This is so as there is no price for damaged or defective goods (Beggin \& Co Ltd v Permanite Ltd 1951) since their value depends on the extent of the damage. (Beco Ltd v Alfa Lawal (1994).

5.2 Contract-based-remedies - These remedies are exercised by the buyer through his legal authority to repudiate contract for the seller's breach of a contractual condition. The breach of a condition entitles a consumer to reject the good and repudiate the contract (Section 12(2) (SOGA). However, the buyer can take any of these options as opposed to repudiation: waive the condition, treat it as breach of warranty, or retain the goods bought and sue for damages (Sections 12(1)2(3) (SOGA). In Henry Stephen Engineering Co Ltd v Complete Home Enterprises (Nig) Ltd (1987), a crane which developed a series of faults soon after delivery was held by the court to be unmerchantable thereby entitling the buyer to reject it. Also in Omotu v Adeleke \& Anor (1975) where a new car developed a disturbing noise five days after purchase was held unfit for its purpose, thereby giving the buyer the right to reject it. It needs be stressed that if there is an unconditional sale of specific goods in deliverable state, property passes at the time of contract (Section 19(1) (SOGA), but some acts by the buyer such as resale (Ajayi $v$ Eburu (1964), intimation of acceptance (Bendel Steel Structures Ltd v Ogbere \& Sons Ltd (unreported)) and lapse of reasonable time had been held by courts to disentitle the consumer or buyer to reject goods sold to him.

5.3 Statutory remedies - These remedies are available to Nigerian consumers through legal, regulatory and institutional frameworks.

5.3.1 Legal and regulatory frameworks: These include -

5.3.1.1 Food and Drugs Act - This Act prohibits the sale of poisonous or harmful foods, drugs and cosmetics and foods that are unfit for consumption (Section 1(1) (a-b) and 2-8). The Act empowers the minister of health to make regulations to expand or restrict the scope of offences under the Act. Under prohibitory sections, the Act stipulates $\$ 50,000$ as fine or imprisonment for a term not exceeding two years or both. This penalty is not deterrent. The Act also makes provision for the appointment of inspecting officers whose duties are amongst others to seize, detain and subject to laboratory analysis contravened foods, drugs and cosmetics (Section 10 of the Food and Drugs Act Cap F.32 LFN 2004) The federal high court has exclusive jurisdiction to try cases under the Act ( Section 17 (a)). 
5.3.1.2 National Agency for Food and Drugs Administration and Control Act, (NAFDAC) 1993:This Act regulates the import, export, production, product adverts and distribution of foods, drugs, chemicals and detergent powder (Section 5 and 24 (5) (a)). The Act establish the National Agency for Food and Drugs Administration and Control and its governing Board. Contravention of the Act or regulations made under the Act attracts a fine of $\$ 50,000$ or imprisonment for a term of one year or both for individuals; and $\$ 100,000$ for body corporate, on conviction (Section 25(2). This penalty is nominal, and cannot be deterrent to offenders in the face of adulterated foods, drugs etc which are detrimental to human and animal health.The Federal High Court is granted exclusive jurisdiction over matters under the Act or regulations.

5.3.1.3 Consumer Protection Council (CCPC) Act, 1992. This Act was repealed in 2018 and replaced with the Federal Competition and Consumer Protection Act (FCCPA, 2018). However the Consumer Protection Act, 1992 made provisions for the establishment of the consumer protection council and state committees which became moribund long before the Act was repealed in 2018. Their duties included interalia, provision of speedy redress to consumers' complaints through negotiation, mediation and conciliation. It also provided for the appointment of inspecting officers who could seize and detain any articles that contravened the Act (Section 15). The Act made it mandatory for manufacturers or distributors of products to notify the public and withdraw their products from the market, on becoming aware of their unforeseen hazardous characteristics, failing which such manufacturers or distributors would pay a fine of $\$ 50,000$ or five years imprisonment on conviction Section 9(1). The Act also empowered consumers to seek redress through state committees and for civil actions for compensation or restitution in a court of competent jurisdiction. The monetary penalty is not commensurate with the imprisonment terms.

5.3.1.4 Trade Malpractices (Miscellaneous Offences Act, 1992 and the Weight and Measures Act LFN 2004: The Acts make deceptive practices illegal in Nigeria. For instance, persons who label, package, sell, offer for sale or advertise any product in a manner that is false or misleading or is likely to create a wrong impression as to its quality, brand name, value, composition, merit or safety commits an offence under the Act (Section 1(1) (a) of the Trade Malpractices (Miscellaneous Offences) Act, 1992.) It is regrettable that the provisions of both statutes overlap on items on weights and measures

5.3.1.5 Criminal Code - This Act prohibits the sale of noxious foods, drinks or articles, the offence of which constitutes misdemeanor which attracts a penalty of one year imprisonment (Section 243(2). This provision of the Criminal Code overlaps the provisions of National Agency for Food and Drugs Administration and Control (NAFDAC) Act, etc.

5.3.1.6 The Federal Competition and Consumer Protection Act, 2018. This Act has replaced the Consumer Protection Act 1992 as pointed out earlier. The objectives of the new legal framework are: to facilitate access by all Nigerian citizens to safe product, secure the protection of rights for all Nigerian consumers (Section 1). Establishes the Competition and Consumer Protection Tribunal (Section 39) and the Federal Competition and Consumer Protection Commission (Section 3). The tribunal is to handle all issues and disputes arising from the Commission as stipulated under the Act.

Other highlights of the Act include applicability, mergers and acquisitions, price regulations and sanctions. The Act applies to all businesses and commercial activities within Nigeria as well as establishments which the Federal, State or Local Government engages in, for commercial purposes or controlling stake, and outside Nigeria in relation to shares or other assets owned by Nigerians resident outside the country, and a person resident in Nigeria who owns shares or other assets outside Nigeria. The Act prohibits agreements made to restrict or restrain competition such as agreement for price fixing, price rigging, collusive tendering etc, but excludes collective bargaining agreements. It repeals the provisions of the Investment and Securities Act in terms of Mergers and Acquisitions, but gives the responsibility of merger transactions approval to the Commission (Section 38). The Act empowers the Nigerian president to regulate prices of goods and services by an order which should be published in the Federal Government Gazette. The commission is given the powers to prescribe fines and sanctions for non-compliance, for instance $10 \%$ of the offending companies' annual turnover in the preceding business year.

The pitfall with FCCPA and its institutional framework is that their impacts are centralized in the federal capital territory (FCT). The commission is overloaded with administrative and quasi-judicial functions. The quasijudicial functions appear to overlap the judicial functions of the Tribunal, for instance, the commission is empowered by Section 18(4) (a-c) to "summon and examine witnesses", "call for and examine documents", "administer oaths" and apply sanctions in section 17(h). There are no provisions for decentralization of the Tribunal in the country to cover the 36 states. Section 3(5) of the Act, however, confers non-binding obligation on the commission to establish "other offices for the purposes of its business in any part of Nigeria as it may determine". Establishment of more offices of the commission will be dependent on availability of financial resources. It may be difficult for the commission to effectively cover the entire country. Penalties for contraventions of the Act as contained in sections 33(3) (b) and (4), 35(3) are to some extent adequate.

To a large extent the Act has complied with the guidelines of UNCTAD, but it is bereft of collective redress, shared competence, wide and effective coverage. 


\subsection{Institutional Frameworks}

These include, interalia the investigating panel under Trade Malpractices (Miscellaneous Offences) Act, NAFDAC, the Commission under the extant Federal Competition and Consumer Protection Act, 2018 and Standards Organization of Nigeria (SON). SON is Statutorily, empowered to set standards for weights, dimensions, size, resistance, sampling and test methods, permitted additives, preservatives, labeling, storage conditions and the relevant ingredients of goods. It also has the power to certify goods through the use of its certification marking system by awarding Nigerian Industrial Standard (NIS) to winning companies or firms. The award of NIS encourages consumers to buy and use such products with the label as it connotes certification mark of quality, hence SON enters into a contract of Guarantee with Nigerian Consumers who can sue it and the manufacturer for negligence should this contract fail.

The Trade Malpractices (Miscellaneous offences) Act and Weights and Measures Act provide for the establishment of investigation panel and inspectors respectively, whose responsibilities are to investigate cases of complaints by consumers and report on same to the Attorney-General of the Federation who will in turn institute proceedings against the offender in the Federal High Court. Sections 5 and 24(5) (a) of NAFDAC Act also provide for the establishment of National Agency for Food and Drugs Administration and Control and its Council. The Agency is empowered to determine the suitability or otherwise of medicines, drugs, food products, cosmetics, medical devices or chemicals for human and animal use.

5.5 Consumer Advocacy Groups

These groups have the responsibility of enlightening and educating consumers in Nigeria as well as facilitating their access to redress channels. They also champion consumers' rights as well as assist them seek redress in courts of competent jurisdiction. The following Consumer Advocacy Groups exist in Nigeria: Consumer Protection Organization of Nigeria (CPON), Consumer Empowerment Organization of Nigeria (CEON), Consumer Rights Advocacy League (CRAL), Consumer Advocacy and Empowerment Foundation (CAEF). Their channels of creating awareness amongst consumers are the radio, television, outreach programmes and conferences (workshops).

\subsection{Consumer Redress Channels in Other Jurisdictions}

It is pertinent to examine consumer redress channels in other jurisdictions such as South Africa, United States of America, European Union and Malaysia to enable an apt comparative analysis between each of them and Nigeria. 6.1 South Africa: The South African approach is holistically vibrant. Here Consumer protection is regulated through her constitution, consumer protection Act (CPA) and provincial legislation. Her constitution provides for concurrent legislative jurisdiction on consumer protection which means that, both the national government and the 9 provinces can legislate on consumer protection (Schedule 4, Part A). This approach is informed by the fact that many South African consumers are poor, illiterate and suffer from various forms of socio-economic inequities and live in remote and low-density areas. The South African Consumer Protection Act (CPA) Act 68 of 2008 was passed in 2008 to protect South African Consumers due to the extant dynamic and complex market environment. It is very comprehensive and has intensive implications on the relationship between buyers and sellers of goods and services in South Africa. It ensures that retailers handle consumer complaints in an efficient manner, vests provision of quality goods and services on all the members of the supply chain (consumers can sue members of the supply chain, if they are dissatisfied), seeks to help businesses to improve their operations, strengthen their relationship with their customers and build their brand equity and strengthen their sustainable existence in the market. The CPA places emphasis on consumer rights, consumer education, co-operative governance between the provinces and the National Consumer Commission (NCC), places obligation on the provinces to play an integral role in the enforcement of the CPA.

The Act also imposes a role on accredited civil society organizations (Section 77) through co-operation with the NCC, to offer consumer advice, engage in education activities, consumer publications, advocacy of consumer interests and promote consumer rights. There is also established the consumer protection forum which has addressed specific consumer education aspects through the development of annual business plans, identification of consumer education programmes and initiatives, joint activity plans which have had both National and Provincial impact. The following consumer education programmes have been implemented in the country:

- Savings month campaign: Emphasizes savings, financial planning and reducing one's exposure to debt.

- Know your consumer rights campaign: It is a campaign on the implementation of CPA and impact of National credit Act (NCA), redress options to consumers, impact of consumer legislation and business and importance of civil society in consumer education.

It needs be noted that eight out of the nine (9) provinces in South Africa have passed their provincial legislation on consumer protection. For instance, Western Cape Province passed its own legislation in 2002 (Western Cape Consumer Affairs (Unfair Business Practices Act, 2002 (Act 10 of 2002). The Act established a provincial office which is statutorily empowered to investigate all consumer complaints in the province, regulates the investigation processes and carry out consumer education. Since 2012 four (4) out of the nine (9) provinces have established 
proactively operational consumer courts/tribunals to handle disputes between consumers and sellers of goods and services.

6.2 United States of America (USA)

The account of consumer protection in the USA is the tale of precise officially authorized reaction, predicament and emergencies that created immense public indignation that necessitates a public response (Waller, S.E. et al 2011). The common law principles of freedom of contract and caveat emptor, over the years since the independence of the USA, contributed to cases of product defect liabilities. The increasing number of product defect liabilities led to the establishment and enactment of many federal, state and local regulatory agencies and laws on consumer protection.

The peak of government protection of consumers was in 1960 when the Late John F. Kennedy evolved and approved the Consumer Bill of Rights which includes, the right to the satisfaction of basic needs, the right to safety, the right to be informed, the right to choose, the right to be heard, the right to redress, the right to consumer education and the right to healthy and sustainable environment (last four were added, by the United Nations).

Although there are no centralized regulatory and institutional frameworks on consumer protection in USA, American consumers today are for the most part sheltered from hazardous goods, deception, misleading advertisement and inequitable businesses by Federal, State and Local legislation as well as high percentage of private rights actions

The Federal Trade Commission (FTC) has investigative authority to investigate consumer complaints and reveal deception, unfair activities and violation of statutes under its jurisdiction. The FTC can issue a complaint to the persons, partnerships or corporations that have violated a statue(s), if violation is detected by it, and subjects such persons, partnerships and corporations to hearing by the Administrative Law Judge. Appeals lie from the judge to the full FTC, Federal Appellate Court and the US Supreme Court. The penalty for violation is $\$ 10,000$ per violation (15 U.S.C.A $745 \mathrm{CI}$ ). Besides, the $\mathrm{FTC}$ also has the powers to make trade regulation rules, for instance, its Telemarketing sales rule. Violation of regulation rules also attract $\$ 10,000$ per violation. The FTC has the powers to restitute victimized consumers by compelling wrong doers to disgorge their ill-gotten gains (15 U.S.C $\& 53$ (b) although it has no criminal jurisdiction.

Other Federal Agencies include Consumer Product Safety Commission (CPSC), Food and Drug Administration (FDA), the National Highway Traffic Safety Administration (NHTSA), the Federal Communications Commission (FCC), the Bureau of Consumer Financial Protection, and Federal Reserve. All have statutory responsibilities that are akin to their names.

The National Traffic and Motor Vehicle Safety Act 1996 seeks to streamline standards in the US automobile industry. The effects of the Act include, the emergence of automobile industry with automobile car safety standards. The Dodd-Frank Wall Street Reform and Consumer Protection Act 2009 with objectives of conducting fiscal tutoring programmes; collect, investigate and respond to consumer grievance; collect,research, monitor and publish sequence, pertinent data of the most favorable performance of markets for consumer fiscal products.

6.2.1 State redress mechanism for consumer protection

The USA's 50 states are also constitutionally empowered to make legislation on consumer protection (Consumer Fraud and Deceptive Business Practices Act, 815 ILCS 505\.) which are enforced by their Attorneys-General. They carry out such enforcements through investigations of violations, prosecution of violators, issuing of injunctions to terminate violations, restitution of victimized consumers and criminal prosecution. The AttorneysGeneral enforce their states' statutes which ban unfair and deceptive acts and practices through issuance of Civil Investigative Demands (CID) which are used to request documents or oral testimonies from violators who may be individuals or companies. Attorneys-General can also elicit voluntary assurance of compliance from violating companies, use civil and criminal procedures to punish unfair or deceptive trade practices and obtain restitution for customers who are sufferers of scam and deceptive practices. States also establish institutional frame-works to regulate energy, transportation, health and financial services. Such regulatory mechanisms are not uniform. They also control trades and professions by way of licensing boards and enforcement divisions.

6.2.2 Consumers' Private Rights of Actions

Consumers' private rights of action are founded in common law (tortuous actions), statutory remedies, Uniform Commercial Code (passed by forty-nine states and Consumer Credit Legislation.

6.2.2.1 Tortious Remedies: These are dominantly used in the states by American citizens. These are also mainly used in actions in fraud, deceit, misrepresentation and breach of warranty. The penalties of these actions are damages, rescission for contractual breach.

6.2.2.2 Statutory Remedies: These are actions that the consumers can bring against deceptive sellers under the Federal Trade Act and State Unfair Trade Practices Statutes. These statutes also grant damages and injunctions. State "lemon" legislation can also be used, as remedies for customers who are deceived into buying defective new or used car. Consumers are also protected under the Uniform Commercial Code of 49 states which are used to protect consumers against product defects by way of warranties (Magnuson Moss Warranty 1975). Warranties could be written or oral, and they refer to express and implied promises by the manufacturers or sellers that they 
will not disown their products.

Consumer credit legislation include the Fair Credit Reporting Act, passed in 1970, and amended in 2003 used by consumers to confirm the authenticity of information about them by their creditors, the Fair Credit Billing Act,1974 Passed as an amendment to Truth in Lending Act 1968 which provides procedures for creditors to quick process billing disputes and corrections, the Fair Debit Collection Act, 1977; and the Credit Card Act (CARD of 2009) which protects consumers from abusive practices by Card issuers, such as arbitrary adjustment of the individual's interest on his credit card.

6.2.3 Consumer Advocacy Groups -These are consumer associations and non-profit organizations. Their roles include investigation, publication, lobbying, litigation and research on consumer matters after which they file complaints with federal or state agencies. Their complaints are informal because they have no statutory right to file super-complaints and collective actions against defaulting manufacturers or sellers. They can, however, sue in their own names in court. These associations and non-profit organizations include Citizen Utility Boards, Consumer Federation of America (provides consumer advocacy for federal and state legislative and statutory bodies, researches consumer behavior and concerns, education and awareness on consumer concerns); Consumers Union (educates consumers on many products).Institute for Consumers Antitrust Studies (deals with the impact of antitrust enforcement and consumer protection law); National Consumer Law Centre(advocacy group for lowincome earners who are affected by deceptive, fraudulent or unfair practices) and public citizen (represent consumer interest before the three arms of government in the US: Executive, Legislature and Judiciary).

6.3 Consumer Redress in Malaysia

Aun (2001) states that the principal legislation for protecting Consumers in their purchase of goods and services in Malaysia is the Consumer Protection Act (CPA) 1999, an Act consisting of 14 parts with 150 sections. Under CPA 1999, grievance from consumers can be suitably tackled and attended to under Section 2(1) of the Act, which deals with all main parts of consumer protection as it applies to the delivery of products and services, buy and sell practices, contract terms, manufactured goods safety, liability and redress method. Consumer redress under the CPA 1999 is addressed through the National Consumer Advisory Council (NCAC) and Tribunal for Consumer Claims (TCC). As stated in Part XI of CPA, NCAC was created to offer guidance on consumer-interrelated issues. With the interest of consumers at heart, NCAC set up the National Consumer Policy (NCP) on 26 July 2002 with the focal point being on balancing of rights and duties of the government, business operatives (e.g. sellers, brokers, and producers), and consumers. The guidelines in general seeks to raise general livelihood, guarantee satisfactory consumer protection, and maintain fair and decent trade, consumer awareness, redress mechanisms, consumer round-table platforms that provide interaction amongst the government, sellers, brokers, producers, and consumers, including international collaboration in consumer- interrelated issues.

Prior to the establishment of the Tribunal for Consumer Claims (TCC), consumer redress were sought out from civil court usually involving multifaceted, expensive, and prolonged actions. Whilst Small claims judicial institutions at the state level were instituted to address consumer claims not exceeding RM 5,000. Amin and Bakar (2010) noted that consumers were reluctant to seek redress against untrustworthy and devious sellers, brokers, and producers of goods or services, for the most part if the damages sought were minimal. As a result, TCC was created in Malaysia with the sole purposes of offering a less tasking and gainful medium to resourcefully reconcile consumer disputes as enshrined in Section 85 Part XII of CPA 1999. The mode of operation of the TCC is independent, working principally on consumer-associated cases and consumer disputes, in line with the stipulations of the Act. TCC initially attended to consumer redress claims not exceeding RM 25,000. However, with the coming into force of the CPA (Amendment) 2019, TCC at the moment addresses consumer claims not exceeding RM 50,000. It is pertinent to note that, consumer claims bothers on delivery matters as relates to goods and services, deceptive trade practices, or misleading commercials or cost tags. In addition, the tribunal attend to consumer claims concerning redress methods not catered for under other laws, irrespective of the fact that the claims are outside of the CPA, provided that it is not clearly excluded from its jurisdiction. It is worthy to note also Part IIIA of the CPA (Amendment) 2010, that protects consumers from discriminating contract terms. Other enactments for Consumer Protection consist of the Consumer Protection (Certificate of Conformance and Conformity Mark of Safety Standards) Regulations 2010, and Electronic Trade Transactions Regulations 2012. 6.4 The European Union (EU) -Consumer protection practices in Austria, Belgium, Bulganin, Germany, Greece, Italy, Poland, Portugal, Spain, Sweden and the United Kingdom (UK) is hereunder discussed.

In 2018 the European Commission (EC) brought out some consumer protection proposals titled "A new deal for consumers." This "new deal for consumers" modernised and effectively catered for the enforcement of consumer protection rules, guaranteed equal treatment for consumers in the European single market. The proposals were informed by the fact that models for the implementation of consumer protection policy and the enforcement of consumer protection laws differ amongst members of the EU because of their different legal and institutional frameworks and socio cultural milieu. The proposal reflect the strengthening of consumer rights, improving the statutory tools for the enforcement of consumer protection and reducing business burdens. These proposal also cover consumer protection issues such as product safety, food safety, food labeling, financial services, tourism and 
leisure, transport, communications and energy.

6.4.1 Increasing the Rights of Consumers - This is a Directive 2011/83/EU that proposes stronger consumers' rights in terms of transparency in online sales or digital services. Online platforms and market places are required to clearly specify whether the seller is a professional trader or a private individual because digital search results by traders are often biased due to their payment for high ranking in the results. This Directive also guarantees the right to individual remedies for consumers who are harmed by unfair commercial practices. These remedies are both contractual and non-contractual such as the right to rescission or termination of contract, the right to compensation for damages (Directive 2005/29/EC.)

6.4.2 Improving the Tools for the Enforcement of Consumers' Rights

Collective redress mechanism is adopted for consumer groups that are qualified organizations/associations, with a view to strengthening private enforcement mechanisms. The entities can stop a traders' unwholesome practices as well as obtain compensation for consumers. The proposals strengthen the sanctioning powers of members of national enforcement authorities through financial penalties. There is consistent enforcement of EU consumer laws across borders and trader who violates such laws are subject to the payment of the maximum fine of at least $4 \%$ of the trader's annual turnover (EC 2018c.) The dual practice of marketing different products in different countries but using the same packaging and branding is prohibited, because it is an unfair commercial practice and misleading.

6.4.3 Reducing Business Burdens

Fitness check is introduced to reduce excessive burdens on traders. Return of products by consumers can be done within 14 days. It entitles traders to refuse the return of a product within 14 days (right of withdrawal of consumers), if the product has been used by the customer.Traders can reimburse the product once it has been returned but not in advance. Approval of new communication tools for traders and consumers such as chats, web forms to enable consumers keep track of their correspondence with traders (Article 6).

6.4.4 Dispute Resolution Machinery

The EU Directive 2013/11/EU introduced Alternative Dispute Resolution (ADR) and Online Dispute Resolution (ODR) mechanisms to solve domestic or national cross-border disputes with traders.

6.4.5 Education and Capacity Building

There has been limited enlightenment and knowledge of rights and obligations by consumers and traders in the EU.Compliance with EU consumer law has been for many years impeded.

\subsection{Comparative Analysis of Consumer Redress Channels between Nigeria and other Jurisdictions}

Other jurisdictions' approaches to consumer redress are multi-dimensional whereas Nigeria approach is just one way. Consumer protection in Nigeria is the sole responsibility of the Federal Government. Consumer protection and redress are a shared competence between the Central Government, the States (regions) and Provinces (local authorities) in other jurisdictions such as South Africa, United States and European Union (EU) countries. The protection of consumer rights and interest is decentralized in these jurisdictions, hence their consumers are consciously made aware of their rights, interest and redress channels they can choose to adopt in the event of settling disputes with suppliers. The obverse is the case in Nigeria.Consumer protection is too centralized to the extent that many Nigerian consumers are not aware of their rights and interest, and they are unaware of the existence of the Institutional and Legal frameworks that they can resort to, to ventilate their complaints and enforce their rights. Many Nigerian Consumers are not even aware that a new consumer protection law was enacted in 2018

South Africa and some jurisdictions have enshrined consumer protection in their constitutions which specify the shared competence and consumer sustainability between national governments, states and local authorities. Nigeria, USA etc are yet to make consumer protection and redress a constitutional matter. Consumer protection and redress should, of extreme necessity, be enshrined in the constitution, as it is the supreme law of a country, and consumer protection policy is pivotal to socio-economic development of all countries.

The enforcement machinery of Nigerian legislation is lax while the enforcement machinery of other jurisdictions under consideration is near perfect. The impact of the Consumer Protection Act 1992 was never felt in Nigeria. Besides, it had become moribund before the enactment of the Federal Competition and Consumer Protection Act 2018. The Act is a fine piece of legislation, and if well implemented will to a large extent abolish the relational disparities and imbalances between Nigerian consumers and suppliers, as well as reduce the abuse and exploitation of Nigeria consumers by suppliers. Consumer awareness and capacity building by the Nigerian government is low. This is because the public agencies involved in consumer protection and redress are not functioning optimally, besides, private entities (consumer associations/organizations) are not funded by the Federal Government to enable them be proactively functional. In other jurisdictions under consideration, these private entities are actively involved in the implementation of consumer policies, enforcement of consumer rights and interests and education and capacity building for their consumers. Consumer protection in other jurisdictions such as the European Union, United States, have been digitalized, and about to be digitalized in South Africa, but 
Nigeria is still far from the digitalization of consumer protection. The non-digitalization of consumer protection in Nigeria could however, be explicable by the poor computer illiteracy in the country (most consumers live in rural areas and are both didactic and computer illiterates). Hence, Online Dispute Resolute (ODR) can only be introduced and to be used by only computer literate Nigerians, who, invariably are very few.

It is only in the European Union countries that the consumer's right to individual remedies has been strengthened and standardized through the provision for collective redress through qualified entities in the EU and national consumer legislation. Representative actions are not provided for under the laws of Nigeria, United States and South Africa. The qualified entities (consumer associations/organizations) can only assist consumers financially to institute court actions against defaulting suppliers for product defects in Nigeria, United States and South Africa.

The EU Law (Directive 2011/83/EU) directly makes provision for the reduction of businesses' burdens through the fitness check. The ingredients of this fitness check are that traders can reject the return of a product within 14 days right of withdrawal if the consumer has used it, even though it is tested (Article 14), traders can reimburse the product once it is returned but not in advance (Article 13), and introduction of new communication tools (charts and web forms) between traders and consumers (Article 6). In the Nigerian Federal Competition and Consumer Protection Act, 2018 the consumer's right of withdrawal or return of defective product is within reasonable time (Section 122). Reasonability in time is usually difficult to define by the courts as it could either be objective or subjective. The use of Ombudsmen for consumer protection and as a redress channel is only pronouncedly utilized in EU countries. The practice is non-existent in Nigeria. They are used, for instance, in Bulgaria to protect the rights and interests of all citizens.In other jurisdictions, litigations for product defect liability cases are handled by the conventional Courts of competent Jurisdiction not tenured Tribunal as in Nigeria. South Africa, for instance, has established consumer protection courts to handle all consumers' complaints.

In Malaysia, The Tribunal for Consumer Claims ("TCCM") subsist as an autonomous legal body and a substitute to courts, for an end user to file a claim for loss experienced in revere of product or services gained or obtained while the Competition and Consumer Protection Tribunal in Nigeria serves to determine appeals from the Commission, or appraise any judgment from the exercise of the powers of any sector with explicit regulatory power in a regulated trade in respect of competition and consumer protection issues.

\subsection{Findings}

The effectiveness of a country's legislation is tied to its levels of leadership. Where leadership is service and purposeful-driven, a country's enforcement machinery will be strong and effective. Where leadership is clueless and purposeless, and acquired for financial and personal aggrandizement, enforcement of laws will be lax because of the attendant corrupt practices that will ensue. The following are findings from this research

- Every member state of UNCTAD tries to adopt its guidelines on consumer protection, although the guidelines are adopted in a way and manner that they must suit the peculiarities of each country's socioeconomic and cultural milieu.

- Most countries are yet to enshrine, the subject of consumer protection in their constitutions' exclusive, concurrent and residual lists to make for three tiers of consumer protection and consumer policy implementation. In a country where there is shared competence in consumer protection, consumers' rights and interests will be proactively protected and pursued by the government.

- Not all countries fund consumer associations/organizations to make them functional. In a country where they are funded, they will have the financial strength to seek redress for consumers in court. Funding them is also sine qua non requirement for effective collective redress. This explains why such associations are weak in Nigeria mechanism.

- The use of ombudsmen for consumer protection appears to be localized in only EU countries. Their importance and significance in the implementation of consumer protection policies by other courtiers and as advocated by UNCTAD cannot be overemphasized.

- Education and capacity building for consumers in Nigeria is unknown or not visible. This is taken very seriously in other jurisdictions under consideration. Educating and building capacities of consumers helps them to become consciously aware of their rights, interest and obligations, thus product defect liabilities can be reduced to some extent.

\subsection{Recommendations}

The following recommendations are made for improved consumer protection and implementation of consumer policy in Nigeria

- The Constitution of the Federal Republic of Nigeria 1999 (as amended) should be amended to include a section on consumer protection which should be placed on concurrent and residual list. The implication of this amendment is that there will be shared competence on consumer protection amongst the Federal, State and Local Governments. The machinery for the implementation of consumer policy and consumer protection 
will be brought nearer the mass of Nigerian consumers who live mostly in local government areas as all the three tiers will be constitutionally required to legislate and enforce consumer protection policies, rights and interests.

- The amended constitution should clothe the consumer entities with the power of collective redress to enable them prosecute cases of product defects on behalf of consumers in Nigerian courts

- Federal, state and local governments should fund consumer entities (associations/organizations) to enhance their financial strength as well as enable them champion the cause of consumers and finance litigations for them in court.

- To meet up with the tenets of globalization, the Federal Competition and Consumer Protection Act, 2018 should be amended and state laws that will be enacted in accord with the amended constitution should also contain rigorous education and capacity building for Nigerian consumers. This will help acquaint them of their rights

- Consumer protection should be introduced as Subjects $\backslash$ Courses in primary, secondary schools and tertiary institutions respectively for early understanding.

- The federal, state and local government should be constitutionally mandated to appoint Ombudsmen to assist the three levels of government to implement consumer protection policy, consumer rights and interest, but the duties should not overlap with the federal and state Ministries of Trade and Commerce, and Health. Ombudsmen are significant for their moral and technical authority.

- Consumers - Sellers dispute resolution and redress should be expanded to include the establishment of expeditious, fair, affordable and accessible redress mechanisms such as Alternative Dispute Resolution (ADR), and Informal Consumer Disputes Resolution by businesses. The principles and practice in dispute resolution should also include collective resolution procedures when dealing with cases of bankruptcy and huge indebtedness.

- Government should provide funding for training in Information and Communication Technology (ICT) as this will enhance Online disputes resolution between the consumer and seller.

- Government - Civil Society Organizations and business partnership is advocated.

- The common law doctrine of "strict liability" should be included in a section in the Federal Competition and Consumer Protection Act 2018 for defective products. Strict liability does not depend on actual negligence or intent to harm but based on the breach of an absolute duty to make something safe. The American Restatement of Torts, makes a manufacturer strictly liable for injuries caused by his product, whereas the United kingdom's Consumer Protection Act, 1987 (Section 4(1)a) provides for strict liability as defence for the consumer.

- The common law doctrine of Privity of contract should be abolished for products defect liability cases only, to promote collective redress mechanism. This doctrine states that only parties to a contract can claim the remedies provided therein. It has since been abolished for products defect liability cases in jurisdictions such as the United States, European Union (EU) which treat such doctrine as an unfair contract term.

\subsection{Conclusion}

Globalization that erupted from the late $20^{\text {th }}$ century has created global goods and services and consumers to the extent that many countries have passed framework legislation to provide their consumers with safeguard that transverse the wide variety of dealings, merchandise and services. This depicts how important and significant consumer protection is regarded by UNCTAD and its member states. The best approach is the mixture of framework legislation and sectoral laws on consumer protection because they are complementary. Nigeria adopts the mixture of both approaches because, besides the CCPA, 2018, there are other legislation that have been passed to protect its consumers, for instance, the Food and Drugs Act, NAFDAC Act, Insurance Act, Legal Practitioners Act etc. Nigeria needs to take urgent steps to amend its constitution as earlier suggested to include consumer protection in its constitution, adopt the recommendations herein stated and strengthen the enforcement machinery of its consumer protection legislation as her consumers now operate within enlarged global marketplace in which the dynamics of interaction between international and Nigerian consumers, businesses and legal framework has changed.

\section{References}

Books

Aasker P.A.\& Day, G.S. (1974) Consumerism, $2^{\text {nd }}$ Ed. New York: Free press

Amin, N. \& E.A. Bakar, (2010) “ADR for consumers: An appraisal of the Tribunal for Consumer Claims Malaysia, in Mohammad Naqib \& Ashgar, Mediation in Malaysia: The law and Practice, Lexis Nexis: Kuala Lumpur. $171-185$

Day RL \& Landon EL Jr, (1977) Consumer and Industrial Buying Behavior, New York: North-Holland. 
Garner, B.A., Black, H.C (2019). Black's Law Dictionary, 11 ${ }^{\text {th }}$ Ed. ST Paul Minnesota, Thomson Reuters. 311

Rachagan, S. S. (1992). Consumer law reform - A report. Kuala Lumpur: University Malaya Press

Robinson, M., \& Davidson, G., (1996) Chambers $21^{\text {st }}$ Century Dictionary, Revised Ed. Allied Chambers (India) Limited, New Delhi.294

The American Restatement of Torts (1965) 2nd edition

The New Webster's International Dictionary of English Language,(2004) International edition, Lechner, D.E.,Lexion Publications.164

W.M. Aun, (2001) Consumer Protection Act 1999: Supply of Goods and Services,” Longman: Malaysia.

Waller, S.E. Consumer Protection in the United State: An Overview, Byola University, Chicago

Journals

A. Iwok \& B. Kooffreh (2014) An Appraisal of the Legal Regime Available for the Protection of Consumers of Telecom Services in Nigeria. Journal of Law, Policy and Globalization, 29

Davidow M \& Dacin PA. (1997) Understanding and Influencing Consumer Complaint Behavior: Improving Organizational Complaint Management. ACR North American Advances, 24:450-456.

Dennis Odigie \& Job Odion (2011) The Impact of Consumers' Protection Laws and the Regulatory Schemes in Nigeria. International Journal of Advanced Legal Studies and Governance, 2, No.1:149.

Etefia E. Ekanem (2011) Institutional framework for Consumers Protection in Nigeria. International Journal of Advanced Legal Studies and Governance, 2, No.1: 44.

Gyasi, S. (2012) Customer Dissatisfaction and Complaining Responses towards Mobile Telephony Services. The African Journal of Information Systems 4:3, 1.

Istanbulluoglu D, Leek S, Szmigin IT. (2017) Beyond exit and voice: developing an integrated taxonomy of consumer complaining behaviour. European Journal of Marketing 51:5/6, 1109-1128.

Hazlina, Shaik Md Noor Alam (2019) The Doctrine of Privity and Consumerism: To Be Or Not To Be. Malaysian Journal of Consumer and Family Economics. 23:151

Mikhaylov AS, Gumenuk IS, Mikhaylova AA.( 2016). Russian public transport system: the customers' feedback on the service provision. Public Transport 8:1, 125-141

Ro H. (2015) Customer dissatisfaction responses to restaurant service failures: insights into non complainers from a relational perspective. Journal of Hospitality Marketing \& Management 24:4, 435-456.

Sampath Kumar.R (2002) Consumerism in India: An overview” Indian Journal of Marketing. 32.

Singh J. 1990. Voice, exit, and negative word-of-mouth behaviors: An investigation across three service categories. Journal of the Academy of Marketing Science 18:1, 1-15.

Singh J, Wilkes RE. 1996. When consumers complain: a path analysis of the key antecedents of consumer complaint response estimates. Journal of the Academy of Marketing Science 24:4, 350-365.

Spencer Weber Waller, Jillian G. Brady and R.J. Acosta (2011) Consumer Protection in the United States: An Overview"- European Journal of Consumer Law. 2

Sune Donoghue and Helena M.de Klerk (2009) The right to be heard and to be understood: a conceptual frame work for consumer protection in emerging economics. International Journal of Consumer Studies. 456

Van Heerde.C \& Barnard .J (2011) Redress for Consumers in terms of the Consumer Protection Act 68 of 2008: A Comparative Discussion. Journal of International Commercial Law and Technology. Vol. 6, Issue 3:138.

Zeti, Zuryani Mohd Zakuan, Rahmah Ismail (2019) Malaysian Journal Of Consumer And Family Economics. Health Supplement And Product Liability In Malaysia: A Call

For Reform 23:33

\section{Statutes}

Constitution of the Federal Republic of Nigeria 1999 (as amended)

Consumer Fraud and Deceptive Business Practices Act.

Consumer Protection Council (CCPC) Act, 1992 CAP C. 25 LFN 2014

Fair Credit Reporting Act, passed in 1970, and amended in 2003

Fair Debit Collection Act; and the Credit Card Act (CARD of 2009)

Federal Competition and Consumer Protection Act, 2018

Food and Drugs Act LFN 2004

Magnuson Moss Warranty 1975

Malaysia Consumer Protection Act (CPA) 1999

Nigerian Consumer Protection Council Act 1992CAPC 25 LFN 2004

Sale of Goods Act, CAP. 30 LFN 2004

South African Consumer Protection Act (CPA) Act 68 of 2008

Trade Malpractices (Miscellaneous Offences) Act, 1992 
Truth in Lending Act 1968

United kingdom's Consumer Protection Act, 1987

United Nations Conference on Trade and Development's (UNCTAD'S) Standards, Guidelines and Best Practices for Consumer Protection UNCTAD

Western Cape Consumer Affairs (Unfair Business Practices Act, 2002)

\section{Cases}

Ajayi v Eburu (1964) NMLR 41

Beco Ltd v Alfa Lawal (1994)

Beggin \& Co Ltd v Permanite Ltd 1951 IKB 422

Bendel Steel Structures Ltd v Ogbere \& Sons Ltd (unreported) suit No W/22/75

Hadley v Baxendale (1854)

Henry Stephen Engineering Co Ltd v Complete Home Enterprises (Nig) Ltd (1987)

Mann Poole v Salami Agbaje(1951)

.Omotu v Adeleke \& Anor (1975) 